\title{
Role of 5\% Tankana bhasma in Gomutra Arka as a Chemical Debridement agent in the Management of Pressure Ulcer - A Case Report
}

\author{
Bolu Kishan Kumar', KM Sweta $^{2}$
}

${ }^{1}$ PG Scholar, ${ }^{2}$ Professor and HOD, Department of PG Studies in Shalya Tantra, Sri Sri College of Ayurvedic Science and Research Hospital, Bengaluru, Karnataka, India.

DOI: https://doi.org/10.24321/2394.6547.202101

\section{I $\quad \mathbf{N} \quad \mathbf{F}$}

\section{Corresponding Author:}

Bolu Kishan Kumar, Department of PG Studies in Shalya Tantra, Sri Sri College of Ayurvedic Science and Research Hospital, Bengaluru, Karnataka, India.

E-mail Id:

krishanartofliving@gmail.com

Orcid Id:

https://orcid.org/0000-0002-6774-2696

How to cite this article:

Kumar BK, Sweta KM. Role of 5\% Tankana bhasma in Gomutra Arka as a Chemical Debridement agent in the Management of Pressure Ulcer - A Case Report. J Adv Res Ayur Yoga Unani Sidd Homeo. 2021;8(1\&2):1-4.

Date of Submission: 2021-04-09

Date of Acceptance: 2021-05-06

\section{$\begin{array}{llllllll}\mathbf{A} & \mathbf{B} & \mathbf{S} & \mathbf{T} & \mathbf{R} & \mathbf{A} & \mathbf{C} & \mathbf{T}\end{array}$}

Background and Objective: Pressure ulcers regarded as preventable but occur in approximately $5 \%$ of all hospitalized patients (range of $3 \%$ to $12 \%$ in published literature). It is more common in paraplegic patients. Only after the complete debridement of slough in grade 3 and grade 4 pressure sores the healing progresses and the infection can be controlled. A chemical solution of 5\%Tankana in Gomutra Arka was reviewed in the management of a case of pressure ulcer.

Presentation of Case: A 26 year old male hemiplegic patient presented with a wound in the sacral region which was diagnosed as a Grade 4 pressure ulcer measuring $12 \times 13 \mathrm{~cm}$. Manual Debridement of ulcer was associated with bleeding.

Methodology: There after the solution of 5\% Tankana in Gomutra Arka was applied upon the wound by soaking a gauge with the above solution. A regular passive movement of the lower part of the body was done to prevent further development of new Ulcer.

Result: After 3 days of dressing $90 \%$ or slough was reduced, discharge from the ulcer reduced and progression of infection had stopped.

Discussion: Pressure ulcers impose an economic burden on the patient and common problem amongst bed ridden patients. Grade 4 pressure ulcers have a poor prognosis. Manual slough removal is usually associated with bleeding. Chemical debridement not only helps us in avoiding instances of bleeding but also is more effective in its reach and action.

Conclusion: In this case 5\% Tankana bhasma in Gomutra Arka was found to be very effective in slough removal which in turn reduced the total duration of management. Use of Chemical debriding agents in a grade 4 ulcer had hastened the process of slough removal and improves the overall rate of recovery. Mixture of Tankana and Gomutra Arka seemed to complement each other's action on Vrana Shodhana.

Keywords: Ayurveda, Chemical Debridement, Slough Removal, Wound Healing 


\section{Introduction}

Earliest reference of management of slow healing ulcers and untidy ulcers is available in Sushrutha Samhita1 an ancient Indian surgical text book, written in 500 BC. 60 interventions have been enumerated and explained in detail about the specific stage wise intervention. Pressure Ulcers of grade 4 can be placed in the category of Dusta Vrana (Non Healing Ulcer) in the Ayurvedic ulcer classification. The treatment indicated for such ulcer are lekhana (debridement), application of powdered and liquid medication for removal of the necrosed tissue that obstructs healing. Pressure Ulcers or Pressure sores can be defined as tissue necrosis with Ulceration due to prolonged pressure. 2 They should be regarded as preventable but occur in approximately $5 \%$ of all hospitalized patients ( range of $3 \%$ to $12 \%$ in published literature). It is more common in paraplegic patients. Only after the complete debridement of slough in grade 3 and grade 4 pressure sores the healing starts and the infection can be controlled. When the area of the ulcer is wide $(>10 \mathrm{~cm})$ the amount of necrosed tissue or slough is considerably large and prone to infection as well. Debridement of such large area is prone to bleeding and makes the overall recovery rate very slow.

Gomutra Arka (Cow urine distillate) is a proven drug which not only helps in providing a antimicrobial action but also helps in removing unhealthy granulation and slough. Tankana Bhasma is also a proven drug for management of slow healing Ulcers. The combination Tankana bhasma and Gomutra Arka in the form of a $5 \%$ concentration of Tankana Bhasma in Gomutra Arka was found to have a synergistic effect and the rate of reduction of slough was more marked when compared to manual debridement alone.

\section{Methodology}

\section{Preparation of 5\% Tankana in Gomutra}

Under aseptic conditions 5grams of Tankana bhasma was mixed with $100 \mathrm{ml}$ of Gomutra arka. Tankana Bhasma and Gomutra arka were from a GMP certified company.

\section{Application}

The ulcer was cleaned with normal saline and then cleaned with a dry gauge. Thereafter the above solution was soaked in the sterile gauge used for dressing to cover the floor of the ulcer followed by covering with a sterile pad dressing.

\section{Presentation of the Case and Course of Treatment}

A 26 year old man suffering with hemiplegia since 2 months presented with a wound in the sacral region measuring $2 \times 3 \mathrm{~cm}$ and surrounding $12 \times 13 \mathrm{~cm}$ area with blackish discolouration since 15 days. On examination it was a pressure ulcer measuring $2 \times 3 \mathrm{~cm}$ with surrounding necrosed tissue. On removing the necrosed skin it was measuring around $12 \times 13 \mathrm{~cm}$ with undermined edges and slough involving the underlying muscle (Grade 4). The length of undermined area under the edges was varying from $7 \mathrm{~cm}$ to $2 \mathrm{~cm}$. The ulcer was in a longstanding bedridden patient, upon the pressure area, with a lot of necrotic tissue and undermined edges which led to the diagnosis of pressure ulcer. Up to 7 days of Manual debridement was marked by multiple bleeding. There after the solution of $5 \%$ Tankana in Gomutra Arka was applied upon the wound by soaking a gauge with the above solution . Regular passive movements of the lower part of the body was done to prevent further development of new Ulcer.

\section{Result}

The dissolution of slough was very much marked and even the separation of slough from the healthy tissue was easy. In 3 days of application of the above solution $90 \%$ of slough removal was achieved. The purulent discharge from the wound also reduced and appearance of healthy granulation tissue was also seen. There after the application was stopped to preserve the healthy granulation tissue. The patient was then discharged after complete instruction to his attendee regarding the methods of sterile dressing and referred to a plastic surgeon for closure with a flap.

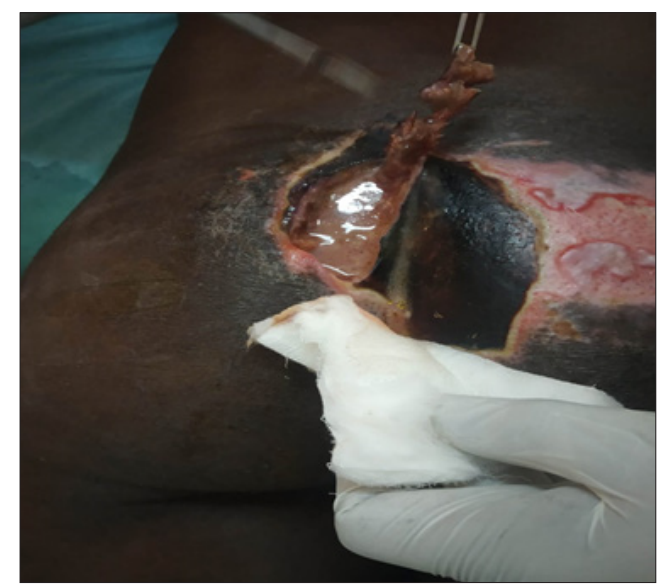

Figure I.Ulcer on the Day of Admission

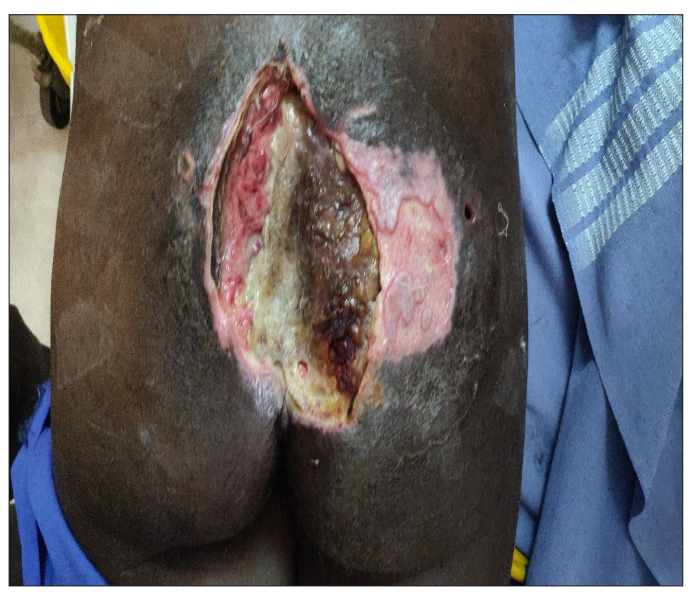

Figure 2.Ulcer after 7 Days of Debridement 


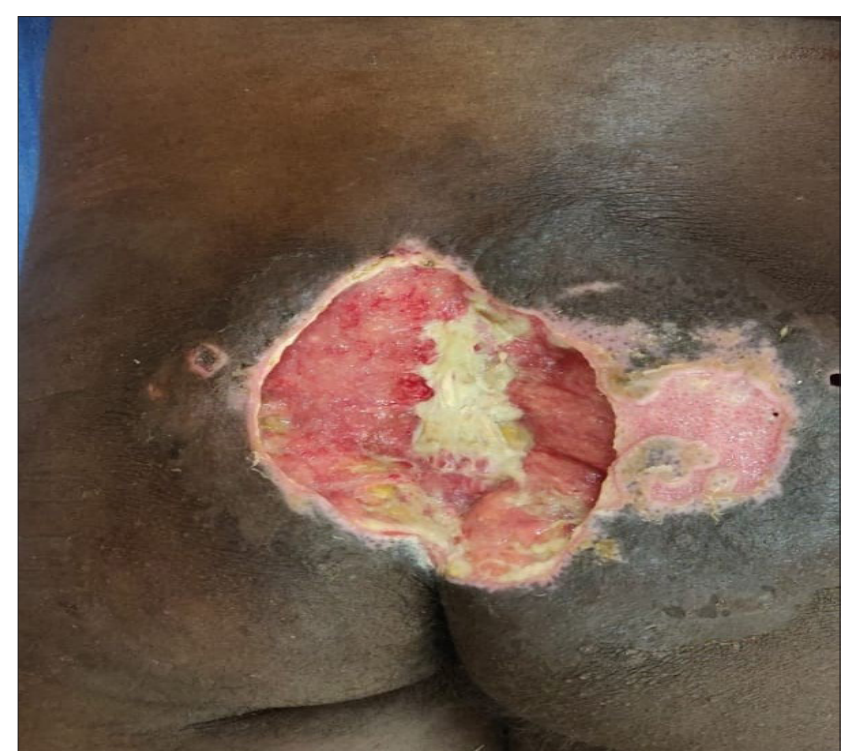

Figure 3.Ulcer On the I I $^{\text {th }}$ Day (3 days of Chemical Debridement with $\mathbf{5 \%}$ Gomutra Tankana Solution) Discussion

Pressure ulcers of grade 3 and 4 can be categorised as Dusta vrana in Ayurvedic Vrana (Ulcer classification). As initially they are non infected, slough removal followed by rapid secondary closure is the suitable way. The primary challenge is transforming an untidy ulcer to healthy ulcer. Manual debridement is not rapid due to the absence of a clear demarcation between viable and unviable tissue, the chance of infection increases. Infection is also a cause of secondary haemorrhage due to sloughing of vessel wall. Use of Chemical debriding agent i.e 5\%Tankana bhasma in Gomutra arka hastens the process of slough removal by a target approach and improves the overall rate of recovery.

Tankana which is among kshara traya has been used since very long in Ayurveda. It has a wide range of therapeutic applications, including diseases like Vrana (ulcers), Shvasa (asthma) etc. The main content of tankana is Boric acid. Purified Tankana Bhasma contains more Boron (13.48\%) than raw tankana (10.08\%). 3 It has been shown in studies that Boric acid has well defined biological effects such as stimulation of wound healing in vivo, release of growth factors and cytokines, increase in the extracellular matrices turn-over.4 Boron decrease the elastase and alkaline phospahatase activity but had no effect on trypsin and collagenase activities.4

In a cell line study of doxorubicin induced carcinoma, the results indicate that Boric acid reduced the formation of DNA double strand breaks caused by agents as well as improving the wound healing process. Therefore, we suggest that boric acid has important therapeutical effectiveness and may be used in the treatment of inflammatory diseases where oxidative stress and wound healing process plays an important role. 5
Gomutra Arka is said to have krimighna properties and the evidences of various studies also have proven its antimicrobial and antifungal activity. 6 Studies have also shown that Gomutra arka also increases granulation tissue and collagen content as well.7 It is also found to enhance the effect of antibiotics. 8

The combination of Gomutra arka and Tankana bhasma in the strength of $5 \%$ solution when applied in a pressure ulcer seemed to synergistically enhance each other's property in slough removal and healthy granulation formation.

\section{Conclusion}

By the use of a chemical agent in liquid form upon slough the area of action increases. 5\% Tankana bhasma in Gomutra Arka was not only effective as a slough removal agent but also stimulated the growth of healthy Granulation tissue. But since its action was found to be Teekshna, hence its impact on the ulcer on long term application needs evaluation. Clinical studies need to be done to evaluate its effective range for usage and also to understand its limitations.

\section{Acknowledgement}

Dr.Naveen B.S, Professor and HOD Department of Shalakya Tantra, Sri Sri College of Ayurvedic Science and research.

\section{Funding Statement: Self \\ Source of Funding: Self}

Conflict of Interest: None

\section{References}

1. Vaidya Jadavji Trikamji Susrutasamhitha of Susruta with Nibhandhasangraha commentry of Sri Dalhanaacharya and the Nyayachandrika Panjika of Sri Gayadasacharya on nidana sthana,Chikitsa Sthana,Varanasi, Choukhamba Surbharati prakashan, Reprint Edition-2017,page 397

2. Bailey and love, Short practice of surgery, 2008 Edward Arnold (Publishers) Ltd, 25 $5^{\text {th }}$ Edition, page no 28-29.

3. Srinivasulu B, Physico-Chemical Standardization of Tanaka (Borax): An Ayurvedic Mineral Drug. The Pharma Innovation2012;6(1);18-25.

4. Nzietchueng RM, Dousset B, Franck $P$, Benderdour $M$, Nabet $P$, Hess $K$. Mechanisms implicated in the effects of boron on wound healing. Journal of Trace Elements in Medicine and Biology [Internet]. 2002 Jan [cited 2020 Apr 14];16(4):239-44. Available from: https://www.sciencedirect.com/science/article/abs/ pii/S0946672X02800517

5. Tepedelen BE, Soya E, Korkmaz M. Boric Acid Reduces the Formation of DNA Double Strand Breaks and Accelerates Wound Healing Process. Biological Trace Element Research [Internet]. 2016 May 6 [cited 2020 Aug 14];174(2):309-318. Available from: https:// 
pubmed.ncbi.nlm.nih.gov/27154731/

6. US6410059B1 - Pharmaceutical composition containing cow urine distillate and an antibiotic - Google Patents [Internet]. Google.com. 2000 [cited 2020 Apr 14]. Available from: https://patents.google.com/patent/ US6410059B1/en

7. Hirapara H, Ghori V, Anovadiya A, Tripathi C. Evaluation of wound healing activity of cow urine ark in diabetic Wistar albino rats. Journal of Intercultural Ethnopharmacology [Internet]. 2016 [cited 2020 Apr 14];5(4):434. Available from: https://www.ncbi.nlm. nih.gov/pmc/articles/PMC5061489/

8. Randhawa GK, Sharma R. Chemotherapeutic potential of cow urine: A review. Journal of intercultural ethnopharmacology [Internet]. 2015 [cited $2020 \mathrm{Apr}$ 14];4(2):180-6. Available from: https://www.ncbi.nlm. nih.gov/pmc/articles/PMC4566776/ 